\title{
A Comparative Analysis of Enzyme-Linked Immunosorbent Assay and Rapid Card Test for Diagnosis of Rotavirus Antigen in Acute Diarrhea Below Five Years Children
}

\author{
Jugal Kishor Agarwal $^{1 *}$, S.P. Garg ${ }^{1}$, Dayachand ${ }^{2}$ and Dipty Agrawal ${ }^{3}$ \\ ${ }^{1}$ Department of Microbiology, SIMS, Hapur, India \\ ${ }^{2}$ Department of Pediatrics, SIMS, Hapur, India \\ ${ }^{3}$ Department of Anesthesia, SDN Hospital, Delhi, India \\ *Corresponding author
}

\begin{tabular}{|c|c|}
\hline & A B S T R A C T \\
\hline Keywords & \multirow{8}{*}{$\begin{array}{l}\text { Group-A Rotavirus are responsible for severe watery diarrhea in young } \\
\text { children. Rapid diagnosis of Rotavirus associated diarrhea can prevent } \\
\text { inappropriate administration of antibiotics and help in preventing the spread } \\
\text { of multi- drug resistance. Rotavirus antigen is detected by ELISA and with } \\
\text { one step rapid antigen test showed an incidence of } 22 \% \text { using ELISA and } \\
21.33 \% \text { using Rapid test respectively. Rapid test showed a sensitivity of } \\
96.97 \% \text { and specificity of } 100 \% \text { in comparison to ELISA. The Rotavirus } \\
\text { infection was highest in age group of } 6 \text { months to } 24 \text { months }(62.77 \%) \text { and } \\
\text { in male ( } 63.64 \%) \text {. The infection was maximum during winter and presented } \\
\text { with triad of diarrhea, vomiting and fever. Majority of cases had watery } \\
\text { diarrhea with severe dehydration. }\end{array}$} \\
\hline ELISA, & \\
\hline Group A & \\
\hline Rotavirus, & \\
\hline $\begin{array}{l}\text { Immuno- } \\
\text { chromatography, }\end{array}$ & \\
\hline Watery diarrhea. & \\
\hline Article Info & \\
\hline $\begin{array}{l}\text { Accepted: } \\
\text { 12 June } 2016 \\
\text { Available Online: } \\
10 \text { July } 2016\end{array}$ & \\
\hline
\end{tabular}

\section{Introduction}

Acute diarrheal disease is a major public health problem leading to high morbidity and significant mortality in both developed and developing countries like India. Rota virus infection is the third most common cause of severe diarrhea in young children Worldwide (Kapikian et al., 1996) Almost all kids have had a Rota virus infection by the time they are 5 years old. It is estimated that Rota Virus infection annually causes 111 million episodes of gastroenteritis requiring home care, 5 million clinic visits, million hospitalization and approximately 600,000 deaths in children less than 5 years of age Worldwide (Parashar et al., 2003). There are seven Rota virus groups known to infect the humans, among them the most dominant is group A (Parashar et al., 2001). WHO estimated that diarrhea is responsible for $18 \%$ deaths among children younger than 5 years of age (Bryce et al., 2005).

In view of high incidence of morbidity and mortality in developing countries like India 
there is a need for rapid and sensitive detection method in routine diagnostic laboratory, which perform antigen detection using enzyme immunoassay (EIA), latex agglutination assay (Bryce et al., 2005) or immuno chromatography. Evidence by direct virus detection using electron microscopy is not practical by routine laboratories. Although Rota virus can be isolated from stool sample by culture, but it is a cumbersome process and needs equipped laboratory require skilled personnel. The recent advance in antigen detection based on immunological techniques using monoclonal antibodies has gained the attention of researchers. Therefore the direct detection of antigen in stool sample by rapid one step assay is inexpensive, easy to handle, non invasive procedure, no specialized instrument is required and have high sensitivity (Cukor et al., 1984).

\section{Materials and Methods}

A prospective study was undertaken between January 2014 to October 2014 in the Microbiology and Pediatrics Department, SIMS, Hapur after obtaining a written \& Informed consent by parents of children below five years with acute diarrhea. Clearance was taken from the ethical committee of the institute.

150 Freshly passed stool, samples were collected in wide mouth sterilized container from hospitalized children and OPD patients of SIMS, Hapur of acute diarrhea by the help of their parents or caretaker and transported to the Microbiology department as soon as possible. Samples were kept at $4^{\circ} \mathrm{C}$ and tested within 24 hours of collection. Rotavirus antigen is detected by immunochromatographic test (SD Bioline test kit) and ELISA kit (premier rotaclones) according to manufacturer's instruction (One step rotavirus antigen test Korea, 2011;
Rotavirus antigen ELISA, 2012).

\section{Results and Discussion}

Rotavirus was found to be a common cause of diarrhea in children less than 5 years of age with an incidence of $22 \%$ using ELISA and $21.33 \%$ using Rapid test.ICG was compared to standard ELISA showed a sensitivity of $96.97 \%$ and specificity of $100 \%$. The infection was maximum during the winter months. Male children (62.7\%) were affected more than female (37.3\%). There was no statistically significant difference in the frequency of rotavirus infection among patients from urban and rural area. A high number of $(72.6 \%)$ of rotavirus positive cases by ELISA presented with a triad of diarrhea, vomiting and fever followed by vomiting preceding diarrhea (21\%) and only diarrhea (6.4\%). Dehydration was significant in children $72 \%$ showed severe dehydration.

In present study, out of 150 patients there were 32 rotavirus positive cases, with Rapid test. When compared to standard test ELISA, Rapid test showed a sensitivity of $96.97 \%$ and specificity of $100 \%$. ELISA is clearly the most sensitive method for detection of rotaviruses and is ideal for screening of large number of fecal specimens in a single sitting.

Now Rapid tests for rotavirus detection are also available such as ICG. This test facilitates qualitative information of rotavirus infection based on the presence of a rotavirus specific band. In addition, the Rapid test (ICG) requires less handling of the sample and quick as the results are available in short time (Momenzadeh et al., 2008).

The present study is matched with observations made by other workers. Momenzadeh et al., compared Rapid test with ELISA for detection of rotavirus. They 
considered ELISA as standard test and found the sensitivity and specificity of ICG to be $87.7 \%, 98.6 \%$, respectively, which is comparable to present study.

Another study done by Dennehy $\mathrm{P} H$ reported the sensitivity, specificity of ICG as $94 \%$ and $100 \%$, respectively and that of ELISA, $95.5 \%$ and $100 \%$ respectively. ICG test was reported as a sensitive, specific and relatively simple test (Dennehy et al., 1999).

Dewar $\mathrm{J}$ et al., found out sensitivity of $88 \%$ (66/75) and a specificity of $100 \%$ of Rapid test when compared with the ELISA. Wilhelmi I et al., compared Rapid test method, with enzyme immunoassay. The statistical values of the enzyme immunoassay, and Rapid test method were respectively $96 \%$ and $99 \%$ for sensitivity; 99\% and $96 \%$ for specificity (Wilhelmi et al., 2001).

In the above study Rapid test technique showed high sensitivity and specificity and was rapid and easy to perform in the routine clinical laboratory. ELISA is the standard test for detection of rotaviruses but because of limited availability and rather high cost we compared ICG to ELISA. In our study sensitivity (96.97\%) and specificity (100\%) of ICG was comparable to ELISA and made the diagnosis simple, rapid, cost-effective and convenient. A study conducted by Momenzadeh, et al., and Kim $\mathrm{J}$ et al., also showed similar results (Kim et al., 2014). Rotavirus accounting $20-50 \%$ of hospitalization for Diarrhea in children worldwide and is the most important cause of death of children (14). The present study showed an incidence of $22 \%$ of rotavirus diarrhea by ELISA in children less than five years of age. The result of this study is supported by other studies from Chandigarh (16-19\%), Kolkata (5-22\%) and Chennai (20.8\%) (Broor et al., 2003).

Majority of infected children in present study were between 6 to 24 months of age $(62.77 \%)$. It appeared that children below 6 months of age were initially protected by maternal antibodies to rotavirus infection and by acquired active immunity after 24 months of age (Saravanan et al., 2004). This result is similar to other studies done in Eastern Nepal and other countries (Shariff $e t$ al., 2003).

In present study $90.47 \%$ cases had watery diarrhea and majority $(76.19 \%)$ are presented with severe dehydration due to elaboration of a potent enterotoxin which causes profuse watery diarrhea, destroys the intestinal epithelial surface leading to blunted villi, extensive damage, and shedding of massive quantities of virus in stools (Glass et al., 2006).

Table.1 Age \& Sex Distribution of Diarrhea Cases

\begin{tabular}{|c|c|c|c|c|c|c|}
\hline Age & Male & $\boldsymbol{\%}$ & Female & $\boldsymbol{\%}$ & Total & \% \\
\hline 6 - 12 months & 25 & $16.67 \%$ & 20 & $13.33 \%$ & 45 & $30.00 \%$ \\
\hline 1 - 2 years & 32 & $21.33 \%$ & 15 & $10.00 \%$ & 47 & $31.33 \%$ \\
\hline 2 - 3 years & 17 & $11.33 \%$ & 13 & $8.67 \%$ & 30 & $20.00 \%$ \\
\hline 3 - 4 years & 9 & $6.00 \%$ & 6 & $4.00 \%$ & 15 & $10.00 \%$ \\
\hline 4- 5 years & 7 & $4.67 \%$ & 6 & $4.00 \%$ & 13 & $8.67 \%$ \\
\hline Total & $\mathbf{9 0}$ & $\mathbf{6 0 . 0 0 \%}$ & $\mathbf{6 0}$ & $\mathbf{4 0 . 0 0 \%}$ & $\mathbf{1 5 0}$ & $\mathbf{1 0 0 . 0 0 \%}$ \\
\hline
\end{tabular}


Table.2 Monthly Distribution of Rotavirus Positive Cases

\begin{tabular}{|c|c|c|c|}
\hline Month & Number of Cases & $\begin{array}{c}\text { Number of Rotavirus } \\
\text { Positive Cases by } \\
\text { ELISA }\end{array}$ & $\begin{array}{c}\text { \% Rotavirus } \\
\text { Positive Cases }\end{array}$ \\
\hline Jan & 20 & 4 & $12.12 \%$ \\
\hline Feb & 13 & 4 & $12.12 \%$ \\
\hline Mar & 20 & 6 & $18.18 \%$ \\
\hline April & 30 & 8 & $24.24 \%$ \\
\hline May & 14 & 3 & $9.09 \%$ \\
\hline June & 11 & 0 & $0.00 \%$ \\
\hline July & 11 & 2 & $6.06 \%$ \\
\hline Aug & 10 & 1 & $3.03 \%$ \\
\hline Sep & 11 & 2 & $6.06 \%$ \\
\hline Oct & 10 & 3 & $9.09 \%$ \\
\hline Total & $\mathbf{1 5 0}$ & $\mathbf{3 3}$ & $\mathbf{1 0 0 \%}$ \\
\hline
\end{tabular}

Table.3 Age \& Sex Distribution of Rotavirus Positive Cases by ELISA

\begin{tabular}{|c|c|c|c|c|c|c|}
\hline Age & Male & $\boldsymbol{\%}$ & Female & $\boldsymbol{\%}$ & $\begin{array}{c}\text { Total } \\
\text { no. of } \\
\text { cases }\end{array}$ & Total \% \\
\hline 6 - 12 months & 8 & $24.24 \%$ & 3 & $9.09 \%$ & 11 & $33.33 \%$ \\
\hline 1 - 2 years & 8 & $24.24 \%$ & 5 & $15.15 \%$ & 13 & $39.39 \%$ \\
\hline 2 - 3 years & 3 & $9.09 \%$ & 3 & $9.09 \%$ & 6 & $18.18 \%$ \\
\hline 3 - 4 years & 2 & $6.06 \%$ & 1 & $3.03 \%$ & 3 & $9.09 \%$ \\
\hline 4- 5 years & 0 & $0.00 \%$ & 0 & $0.00 \%$ & 0 & $0.00 \%$ \\
\hline Total & $\mathbf{2 1}$ & $\mathbf{6 3 . 6 4 \%}$ & $\mathbf{1 2}$ & $\mathbf{3 6 . 3 6 \%}$ & $\mathbf{3 3}$ & $\mathbf{1 0 0 . 0 0 \%}$ \\
\hline
\end{tabular}

Table.4 Diarrhea in various Age Groups

\begin{tabular}{|c|c|c|c|}
\hline Age & Total No. of Cases & $\begin{array}{c}\text { ELISA } \\
\text { No. }(+/-)\end{array}$ & $\begin{array}{c}\text { Rapid Test } \\
\text { No. }(+/-)\end{array}$ \\
\hline 6 - 12 months & 45 & $11 / 34$ & $10 / 35$ \\
\hline 1 - 2 years & 47 & $13 / 34$ & $13 / 34$ \\
\hline 2 - 3 years & 30 & $6 / 24$ & $6 / 24$ \\
\hline 3 - 4 years & 15 & $3 / 12$ & $3 / 12$ \\
\hline 4- 5 years & 13 & $0 / 13$ & $0 / 13$ \\
\hline Total & $\mathbf{1 5 0}$ & $\mathbf{3 3 / 1 1 7}$ & $\mathbf{3 2 / 1 1 8}$ \\
\hline
\end{tabular}


Table.5 Comparison of Rapid Test with ELISA

\begin{tabular}{|c|c|}
\hline Sensitivity & $96.97 \%$ \\
\hline Specificity & $100.00 \%$ \\
\hline Positive Predictive Value & $100.00 \%$ \\
\hline Negative Predictive Value & $99.15 \%$ \\
\hline Accuracy & $99.33 \%$ \\
\hline
\end{tabular}

Table.6 Statistical Significance of Rotavirus with respect to months

\begin{tabular}{|c|c|c|c|c|}
\hline \multicolumn{2}{|c|}{ Observed Value } & $\begin{array}{c}\text { Cooler Months } \\
\text { (Oct - Feb) }\end{array}$ & $\begin{array}{c}\text { Hotter Months } \\
\text { (Mar-Sep) }\end{array}$ & Total \\
\hline \multirow{2}{*}{$\begin{array}{c}\text { Rotavirus } \\
\text { Cases }\end{array}$} & Positive & 11 & 22 & 33 \\
\cline { 2 - 5 } & Negative & 32 & 85 & 117 \\
\hline \multicolumn{2}{|c|}{ Total } & $\mathbf{4 3}$ & $\mathbf{1 0 7}$ & $\mathbf{1 5 0}$ \\
\hline
\end{tabular}

Table.7 Statistical Significance of Rotavirus with respect to Age Group

\begin{tabular}{|c|c|c|c|c|}
\hline \multicolumn{2}{|c|}{ Observed Value } & 6 months to 2 years & More than 2 years & Total \\
\hline \multirow{2}{*}{$\begin{array}{c}\text { Rotavirus } \\
\text { Cases }\end{array}$} & Positive & 24 & 9 & 33 \\
\hline & Negative & 68 & 49 & 117 \\
\hline \multicolumn{2}{|c|}{ Total } & 92 & 58 & 150 \\
\hline
\end{tabular}

In conclusion, rotavirus was significantly associated with diarrhea in children of 6-24 months of age, more in male children, associated with severe dehydration, vomiting, and fever. It is not routinely diagnosed in most of the hospitals due to non availability of tests and its clinical spectrum of signs and symptoms which are mimics to other types of diarrhea. In India few hospitals use ELISA for the diagnosis of Rota Virus infection because of limited availability and cost. On the other hand Rapid test showed a sensitivity of $96.97 \%$ and specificity of $100 \%$ in comparison to ELISA, that is good agreement with ELISA. It has the advantage of being a quicker, costeffective, and useful for testing even a single specimen, convenient, not requiring additional equipments, readily available, simple to perform and easy-to-read results.

\section{Acknowledgement}

JKA and DC collected the data, SPG guided the study, and DA critically reviews the article.

\section{References}

Broor, S., Ghosh, D., Mathur, P. 2003. Molecular epidemiology of rotavirus in India. Indian J. Res., 118: 59-67.

Bryce, J., Boschi - Pinto, C., Shibuya, K., Black, R.E. 2005. WHO estimate so the causes of death in children Lancet, 365(9465): 1147-52. 
Cukor, G. 1984. Detection of Rotavirus in human stools by using monoclonal antibody. J. Clin. Microbial., 19: 888-892.

Dennehy, P.H., Hartin, M., Nelson, S.M., and Rebing, S.F. 1999. Evaluation of the immuno card STAT Rotavirus assay for detection of group A Rotavirus in fecal specimens. J. Clin. Microbiol., 37(6): 1977-1979.

Dewar, J., de Beer, M., Elliott, E., Monaisa, P., Semenya, D., Steele, A. 2005. Rapid detection of rotaviruses - are laboratories underestimating infection in infants, South African Med. J., 95(7): 494-5.

Estees, M.K. Rotavirus and their replication. In: Knipe DM, Howley PM, (eds) fields virology. Philadelphia: Lipin cott - Raven, 2001: PP. 1747-1785.

Glass, R.I., Parashar, U.D., Bresee, J.S., Tureios, R., Fischer, T.K., Widdowsen, M.A., et al. 2006 . Rotavirus Vaccines: Current Prospects and Future Challenges. Lancet, 368: 323-32.

Glass, R.I., Parashar, U.D., Bresee, J.S., Tureios, R., Fischer, T.K., Widdowsen, M.A., et al. 2006. Rotavirus Vaccines: Current Prospects and Future Challenges. Lancet, 368: 323-32.

Wilhelmi, I., J. Colomina, D. MartínRodrigo, E. Roman and A. SánchezFauquier New Immunochromatographic Method for Rapid Detection of Rotaviruses in Stool Samples Compared with Standard Enzyme Immunoassay and Latex Agglutination Techniques. Eur. J. Clin. Microbiol. Infect. Dis., 20(10): 741-3.

Kapikian, A.Z., Chamock, R.M. 1996. Rotavirsus. In: fields BN Knipe DM, Howley PM, et al. eds. Fields virology. $3^{\text {rd }}$ endn. Philadelphia: Lippin cott - Raven, PP 1657-1708.

Kim, J., Kim, H.S., Kim, H.S., Kim, J.S., Song, W., Lee, K.M., et al. 2014. Evaluation of an Immunochromatographic Assay for the Rapid and Simultaneous Detection of Rotavirus and Adenovirus in Stool Samples. Ann. Lab. Med., 34(3): 216-22.

Mitchell, D., Jiang, X., Matson, D. 2000. Gastrointestinal infections. In: Storch GA, et. Essentials of Diagnostic virology. New York: chruchill living stone, 2000:PP. 83.

Momenzadeh, A., Shahrzad, M., Faraji, A., Motamedi, rad1. M., Sohrabi,1.A., Modarres1, S., Azarnoush, L., Mirshahabi1, H. Comparison of Enzyme Immunoassay, Immunochromatography, and RNA-Polyacrylamide-Gel Electrophoresis for Diagnosis of Rotavirus Infection in Children with Acute Gastroenteritis. Iran J. Med. Sci., 33(3): 173.

One step rotavirus antigen test Korea: standard diagnoses tics, Inc; Dec 2011.

Parashar, U.D., Hummel mane, G. 2003. Breese JS, Miller MA, Glass RI. Global illness and death. Caused by Rotavirus disease in children. Emerg. Infect. Dis., 9: 565-572.

Rotavirus antigen ELISA. USA: DRG International, Inc; 2012.

Saravanan, P., Ananthan, S., Ananthasubramanian, M. 20004. Rotavirus Infection among infants and young children in Chennai, South India. Indian J. Med. Microbiol., 22(4): 212-21.

Shariff, M., Deb, M., Singh, R. 2003. A study of diarrhea among children in eastern Nepal with reference to rotavirus. Indian J. Med. Microbiol., 21(2): 87-90.

\section{How to cite this article:}

Jugal Kishor Agarwal, S.P. Garg, Dayachand and Dipty Agrawal. 2016. A Comparative Analysis of Enzyme-Linked Immunosorbent Assay and Rapid Card Test for Diagnosis of Rotavirus Antigen in Acute Diarrhea Below Five Years Children. Int.J.Curr.Microbiol.App.Sci. 5(7): 289-294. doi: http://dx.doi.org/10.20546/ijcmas.2016.507.030 